\title{
Infrastructure Challenges in East and South Asia
}

\section{Stephen Jones}

\begin{abstract}
1 Introduction
This article reviews the challenges for infrastructure policy and investment in East and South Asia. The context is one in which the major economies (led by China and more recently India) have enjoyed increasingly rapid growth accompanied by substantial reductions in poverty. Infrastructure investment has played an important part in this growth, but the increasing demands related to growth have also highlighted shortfalls in the quantity and quality of infrastructure and this is increasingly seen as a binding constraint on accelerating growth further, particularly in India.
\end{abstract}

Infrastructure poses particular policy challenges because of its economic characteristics and these are central to an understanding of the policy options and ways to attract sustainable investment. Key defining features of infrastructure are:

- First, that it is a capital good, so services are produced by combining this with other inputs and tend to have substantial economies of scale

- Second, that it generally has network characteristics (so the value of an investment is related to that of complementary investments that develop and complete a network)

- Third, it is long-lasting and space-specific, implying high sunk costs.

Typically, there are technologies for producing services (such as electricity) that have a range of levels of infrastructure intensity, but producing the services internationally competitively requires the use of infrastructure. The importance of sunk costs means that investors in infrastructure assets face the risk of predatory interference. This may take the form of rent-seeking, or a political response to social pressures to keep the price of basic services low. The combination of sunk costs and network externalities make the regulatory role of government and how it is carried out particularly central compared with other forms of investment where securing returns on private investment is likely to be easier. As noted in the next section, there is international evidence that infrastructure investment tends in aggregate to be undersupplied relative to its economic value, reflecting the significance of these market failures.

The Connecting East Asia study (CEA) (ADB/JBIC/WB (2005) [CEA]) identified three main challenges for the East Asia and Pacific region, while recognising significant differences between the challenges facing at least three main groups of countries - fast growers (China, Vietnam), countries whose recovery from the 1997 crisis has been slow (Indonesia, the Philippines) and countries that are particularly poor and underdeveloped (Cambodia, Lao PDR, Myanmar).

The first is to service and finance the infrastructure needs associated with rapid growth, in a context where the high hopes of the 1990s for the ability of private finance to meet infrastructure needs have largely not been met. This is an issue both about how to mobilise public and private investment to establish and strengthen national networks and how to establish policy frameworks that are attractive for investment and generate flows of revenue to cover investment costs.

The second is to address particular challenges associated with structural change in the demand for infrastructure particularly associated with rapid urbanisation and environmental problems.

The third is to ensure that infrastructure is used effectively to make the pattern of growth that Asian 
countries have enjoyed (which has tended to be highly concentrated geographically particularly around major cities and zones that provide the bulk of export production) more inclusive. Geographically, this involves spreading access to networks to lagging or remote areas, and socially to ensure achievement of the Millennium Development Goals (MDGs), where water and sanitation investment is likely to have particularly high returns, and well-targeted physical infrastructure investment can be complementary to measures to invest in human capital.

The situation in South Asia differs in some significant respects from that in East Asia. First, the growth performance has been much weaker, and the significant acceleration in India's growth is a very recent phenomenon and levels of investment remain far below those of the faster growing East Asian economies. Second, and related, the pace of urbanisation has been slower, although rapid urbanisation remains a major feature. Third, levels of current infrastructure provision and of human capital are generally much weaker (and probably more unevenly distributed in important respects) than in East Asia.

For the most successful East Asian countries, the challenge is to build on and manage the consequences of rapid growth or for countries that have grown rapidly in the past like Indonesia to recapture and improve on a lost growth dynamic. While India, Bangladesh and Pakistan have seen recent improvements in growth (in the case of Pakistan following a long period of stagnation), the prospects for increasing growth to the levels at which a sustained and substantial reduction in poverty (as has been achieved in China and Vietnam) will depend on overcoming infrastructure constraints that currently are binding on growth. This is not just a matter of increasing public investment, though there are reasons for concern that levels of public investment are too low, but also of improving the policy environment and addressing deep-seated institutional constraints.

The remainder of the article is structured as follows Section 2 reviews information on the need for infrastructure in Asia in relation to its role in boosting economic growth, making economic growth more inclusive, and promoting the attainment of the MDGs. Section 3 examines policy questions in relation to the capacity to mobilise the investment resources required and to ensure they are used in an efficient and productive way that promotes poverty reduction. Section 4 summarises the main conclusions.

\section{Infrastructure needs and challenges in Asia} 2.1 The role of infrastructure growth in poverty reduction

While the central importance of physical infrastructure for economic growth and poverty reduction has always been recognised, the recent development of internationally comparable datasets and an intensified international research effort have enabled more strongly based empirical conclusions to be developed. The general conclusions of the international literature (Estache 2004; Jones 2004a) as they are relevant for Asia may be summarised as follows:

- There is strong international evidence that infrastructure investment is central both for accelerating growth and for reducing inequality and making growth patterns more pro-poor.

- Additional growth and poverty reduction benefits are associated with particular sectoral investments, notably in water and sanitation and

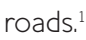

- There is evidence that at the margin, economic returns to infrastructure investment are high (suggesting there has typically been underinvestment), and within developing Asia evidence from comparative studies of different regions that there is a high economic and poverty reduction impact from rural roads investment, particularly when complemented by other forms of public expenditure, notably education.

- There has been limited progress in the Asian region in implementing key institutional and policy reforms for infrastructure (lagging well behind Latin America and Eastern Europe for instance).

In understanding the linkages between infrastructure and growth and poverty reduction, it is important to distinguish between, first, issues related to infrastructure investment and the regulation and provision of infrastructure services that are provided using the capital created and, second, between the direct impact of infrastructure services - that is the effect on users of the services - and the indirect impact - for instance the provision of a port may have little direct impact on semi-skilled workers since they do not directly use its services, but the indirect effect on the demand for their labour from export 
Table 1 Comparative infrastructure indicators across developing regions

\begin{tabular}{|c|c|c|c|c|c|c|}
\hline Region & AFR & EAP & ECA & LCR & MNA & SAR \\
\hline Population (million) & 674 & 1,823 & 474 & 518 & 300 & 1,378 \\
\hline Percentage living on less than \$1-a-day & 46 & 15 & 4 & 10 & 2 & 31 \\
\hline Percentage urban population & 36 & 43 & 65 & 77 & 59 & 28 \\
\hline Percentage urban population projected by 2030 & 51 & 62 & 70 & 85 & 70 & 42 \\
\hline \multicolumn{7}{|l|}{ Major access indicators } \\
\hline $\begin{array}{l}\text { Electricity (percentage of population with access } \\
\text { to network) }\end{array}$ & 24 & 88 & 99 & 89 & 92 & 43 \\
\hline $\begin{array}{l}\text { Water (percentage of population with access to } \\
\text { improved sources) }\end{array}$ & 58 & 78 & 91 & 89 & 88 & 84 \\
\hline $\begin{array}{l}\text { Sanitation (percentage of population with access } \\
\text { to improved sanitation) }\end{array}$ & 36 & 49 & 82 & 74 & 75 & 35 \\
\hline $\begin{array}{l}\text { Roads (percentage of rural population living within } \\
2 \mathrm{~km} \text { of an all-season road) }\end{array}$ & 34 & 95 & 77 & 54 & 51 & 65 \\
\hline $\begin{array}{l}\text { Teledensity (fixed line and mobile subscribers per } \\
1,000 \text { people) }\end{array}$ & 62 & 357 & 438 & 416 & 237 & 61 \\
\hline
\end{tabular}

Table 2 Summary of infrastructure access indicators

\begin{tabular}{lllllll}
\hline & Electricity & Water & Sanitation & Teledensity & $\begin{array}{l}\text { Road density } \\
\text { (population) }\end{array}$ & $\begin{array}{l}\text { Road density } \\
\text { (area) }\end{array}$ \\
\hline Afghanistan & 5 & 13 & 8 & 12 & - & 32 \\
Bangladesh & 25 & 75 & 48 & 16 & 1.6 & 1594 \\
Cambodia & 10 & 34 & 16 & 38 & 1 & 70 \\
China & 97 & 77 & 44 & 424 & 1.4 & 189 \\
India & 40 & 86 & 30 & 71 & 3.2 & 1115 \\
Indonesia & 80 & 78 & 52 & 127 & 1.7 & 203 \\
Myanmar & 5 & 80 & 73 & 8 & - & - \\
Nepal & 15 & 84 & 27 & 18 & 0.6 & 107 \\
Pakistan & 55 & 90 & 54 & 44 & 1.8 & 334 \\
Sri Lanka & 75 & 78 & 91 & 122 & - & - \\
Vietnam & 60 & 73 & 41 & 88 & 1.2 & 287 \\
\hline
\end{tabular}

Electricity: percentage access to electricity network; Water: percentage access to improved water sources; Sanitation: percentage access to improved sanitation; Teledensity: telephone subscribers per 1,000 population; Road density (population): road km/1,000 people; Road density (area): road km/1,000 sq km.

Source Estache and Goicoechea (2005). 
Table 3 Commercial perceptions of quality of infrastructure services

\begin{tabular}{|c|c|c|c|c|c|}
\hline & Electricity & Water & Telephone & Road services & Port facilities \\
\hline Afghanistan & - & - & - & - & - \\
\hline Bangladesh & 2.0 & 3.8 & 1.8 & 3.9 & 2.2 \\
\hline Cambodia & - & 3.0 & - & 4.2 & - \\
\hline China & 4.6 & 4.9 & 5.5 & 4.6 & 3.8 \\
\hline India & 2.7 & 4.6 & 5.6 & 3.3 & 3.0 \\
\hline Indonesia & 3.4 & 4.8 & 4.5 & 4.2 & 2.9 \\
\hline Myanmar & - & - & - & - & - \\
\hline Nepal & - & - & - & - & - \\
\hline Pakistan & - & 4.0 & - & 4.5 & - \\
\hline Sri Lanka & 2.9 & - & 5.4 & - & 4.9 \\
\hline Vietnam & 3.8 & - & 4.8 & - & 2.9 \\
\hline
\end{tabular}

1=worst; 7=best

Estache and Goicoechea (2005).

producers may be substantial. Growth impacts of infrastructure largely work through the impact on the costs of production for enterprises. Several general points about the poverty linkages can be made that set the scene for more detailed discussion of issues within the region:

- In terms of direct impact on the poor, water and sanitation services (mainly through their impact in improving health outcomes), roads, information and communication technologies (ICT), and electric power are likely in general to be of the greatest significance

- Indirect impacts are more difficult to assess and are highly context-specific, but depend on the growth and employment generation impact - in the short-term in particular on the types of investment that are facilitated in relation to their demand for labour

- ICT, electric power and road transport are likely to be of particular significance in relation to wider empowerment-based concepts of poverty.

The empirical significance of public investment in infrastructure in the region and internationally has been examined by lanchovichina and Kacker (2005) in the context of developing models to forecast growth over the period 2005-14 and to identify the contribution of different elements to growth. They conclude that a significant increase in investment is required to improve growth rates. They find for example that improvements in public infrastructure investment could add 0.85 per cent per annum to economic growth over 2005-14 in China, 0.80 per cent in Indonesia, 1.32 per cent in India, 0.45 per cent in Bangladesh and 0.30 per cent in Pakistan.

\subsection{Access to infrastructure in Asia}

Table 1 provides a summary of comparative indictors of infrastructure access across developing regions, and indicates the large gap on almost all indicators (except water access) between East Asia and South Asia.

A more detailed overview of current access to infrastructure in selected developing Asian countries is provided by Table 2 . This shows marked difference in both the overall level of infrastructure access between countries, and differences in the overall characteristics of infrastructure provision reflecting past investment priorities. For instance, China has near universal access to the electricity network compared with access for only 40 per cent of the population in India, while India scores significantly higher than China in relation to access to improved water sources. Among these countries, Afghanistan, Cambodia, and Myanmar stand out as particularly lagging in terms of the proportion of the population connected to key national infrastructure networks. 
Table 4 Estimated annual investment needs, 2005-10

\begin{tabular}{|c|c|c|c|c|c|c|c|c|}
\hline & $\begin{array}{l}\text { Electricity } \\
\text { generation }\end{array}$ & $\begin{array}{l}\text { Telephone } \\
\text { mainlines }\end{array}$ & $\begin{array}{l}\text { Paved road } \\
\text { length }\end{array}$ & $\begin{array}{l}\text { Rail road } \\
\text { length }\end{array}$ & Mobile & Water & Sanit & n Total \\
\hline \multicolumn{9}{|c|}{ East Asia and Pacific: New investment needs } \\
\hline US\$ billion p.a. & 25.0 & 17.0 & 12.1 & 0.2 & 41.2 & 1.8 & 2.6 & 99.9 \\
\hline (\% GDP) & 0.92 & 0.63 & 0.45 & 0.01 & 1.51 & 0.07 & 0.10 & 3.67 \\
\hline \multicolumn{9}{|c|}{ East Asia and Pacific: Maintenance needs } \\
\hline US\$ billion p.a. & 18.4 & 16.8 & 8.5 & 1.4 & 26.1 & 3.6 & 4.2 & 79.0 \\
\hline (\% GDP) & 0.67 & 0.62 & 0.31 & 0.05 & 0.96 & 0.13 & 0.15 & 2.90 \\
\hline \multicolumn{9}{|c|}{ South Asia: New investment needs } \\
\hline US\$ billion p.a. & 11.1 & 3.2 & 6.6 & 0.1 & 3.4 & 1.9 & 1.7 & 28.1 \\
\hline$(\%$ GDP) & 1.21 & 0.35 & 0.72 & 0.01 & 0.37 & 0.21 & 0.19 & 3.06 \\
\hline \multicolumn{9}{|c|}{ South Asia: Maintenance needs } \\
\hline US\$ billion p.a. & 7.0 & 3.4 & 15.8 & 1.4 & 1.8 & 3.3 & 2.4 & 35.0 \\
\hline$(\%$ GDP) & 0.76 & 0.37 & 1.72 & 0.15 & 0.20 & 0.36 & 0.26 & 3.82 \\
\hline
\end{tabular}

Fay and Yepes (2003).

These figures typically hide substantial regional and rural urban differences, and in the larger countries in particular, between provinces, states, and regions. For instance in China the rural teledensity varies from a maximum of 2,760 in Shanghai province to a minimum of 42 in Guizhou (Jones 2004a: Table 11).

Table 3 provides some comparative evidence on the quality of infrastructure services as viewed by business. They suggest that with some exceptions, the quality of electricity services and port facilities are generally regarded as weaker than water or telephone services, with telephone quality rated high especially in those countries which have attracted private capital into the telephone sector.

\subsection{Infrastructure investment requirements in Asia}

Table 4 provides estimates of the annual infrastructure investment requirements in key sectors for East Asia and South Asia. These estimates are based on projected demand in relation to future growth prospects over the period to 2010. They are not based on estimates of the requirements to meet particular targets for access, such as those implied by the MDGs, and do not distinguish between private and public sources of financing, nor do they take account of further possible efficiency gains. The estimates imply that Asian countries will need to invest something around 6.5-7 per cent of their gross domestic product (GDP) to meet demand the implication being that rates of investment lower than this will lead to increasing infrastructure constraints on growth. While directly comparable comprehensive estimates of these figures with current levels of investment in the region are not available, it appears likely that only China and $V_{\text {ietnam }}^{2}$ among the countries reviewed are achieving this level of investment.

There is evidence in a number of countries of falling shares of GDP being allocated to public investment. For example, in India in 1990, infrastructure investment was 5.4 per cent of GDP of which 4 per cent was funded by the public sector. By 1998 this total had fallen to 4.6 per cent with the public sector falling to 3 per cent. The small increase in private sector financing was not sufficient to offset the impact of the public sector fall (Briceno-Garmendia et al. 2004: 17). CEA notes (Table 2) that the proportion of GDP allocated to infrastructure investment varies significantly with China, Thailand and Vietnam spending more than 7 per cent of GDP, while Cambodia, Indonesia and the Philippines spend less than 4 per cent. In Indonesia, central government development spending fell from almost US\$14 billion in 1994 (of which 57 per cent was for infrastructure) to less than US\$5 billion in 2002 (with only 30 per cent for infrastructure). At the same time private commitments to infrastructure investment fell from a peak of over US\$6 billion in 1996 to around US\$0.5 billion in 2000, before recovering to around US\$2 billion in 2002. In the Philippines public expenditure 
Table 5 Investment as a percentage of GDP

\begin{tabular}{lllll}
\hline & \multicolumn{2}{l}{ Gross fixed capital formation as \% GDP } & \multicolumn{2}{l}{ Private foreign investment as \% GDP } \\
& $\mathbf{1 9 9 0}$ & $\mathbf{2 0 0 4}$ & $\mathbf{1 9 9 0}$ & $\mathbf{2 0 0 3}$ \\
\hline Afghanistan & - & - & - & - \\
Bangladesh & 17.1 & 23.4 & 0.0 & 0.2 \\
Cambodia & 8.2 & 22.7 & - & 2.8 \\
China & 25.5 & 45.0 & 1.2 & 4.5 \\
India & 22.9 & $22.7^{*}$ & 0.0 & $0.8^{*}$ \\
Indonesia & 28.3 & 21.0 & 1.0 & 1.7 \\
Myanmar & 14.9 & - & - & - \\
Nepal & 16.1 & $19.1^{*}$ & 0.0 & 0.3 \\
Pakistan & 17.3 & 16.1 & 0.6 & 0.7 \\
Sri Lanka & 22.5 & 25.0 & 0.6 & 1.4 \\
Vietnam & - & $33.0^{*}$ & - & $4.0^{*}$ \\
East Asia & 27.1 & 38.4 & 1.7 & 3.9 \\
South Asia & 21.8 & 21.9 & 0.1 & 0.8 \\
\hline
\end{tabular}

*One year earlier; GDP: gross domestic product. World Development Indicators 2005, World Bank.

on infrastructure investment halved as a proportion of GDP from a peak in 1995 to 2004, when the total was only just over 1 per cent of GDP (Jones 2004a).

Table 5 provides summary information on gross fixed capital formation (i.e. infrastructure investment plus other forms of fixed capital investment) as a proportion of GDP comparing 1990 and 2004 for selected countries to provide some context. Investment is substantially higher in China and Vietnam than in any of the other countries and has also increased over the period. In both India and Pakistan the proportion of GDP invested was lower in 2004 than in 1990, as was also the case in Indonesia. Foreign direct investment has increased in both regions but was almost non-existent in 1990 in South Asia, and remains almost five times higher as a proportion of GDP in East Asia.

A key point then is that overall investment rates either need to be increased substantially or the efficiency of investment needs to be improved both to support currently projected growth and even more so if growth rates are to be sustainably accelerated in the weaker performing countries. This is likely to require both a reorientation of public spending towards longer-term investment, and measures to attract private investment. $A$ detailed analysis of the fiscal space for increasing infrastructure spending or the returns to reorienting public spending towards infrastructure is outside the scope of this article, though it can be noted that in Indonesia and the Philippines, the fiscal impact of the 1997 crisis (and the negative impact on private perceptions of investment risk in infrastructure related to some high-profile contract defaults and renegotiations) has proved particularly deep and long-lasting, while India and Pakistan have faced problems of fiscal adjustment over the period since 1990, which hit public investment especially hard.

CEA also notes that as well as economic growth, rapid rates of urbanisation in East Asia are creating a particularly rapid increase in the need for urban and peri-urban infrastructure (although the large majority of poor people continue to be in rural areas in East Asia). Table 6 illustrates that the rate of urbanisation in South Asia has been considerably slower and is 


\begin{tabular}{lll}
\hline Table 6 Percentage of urban population & & \\
\hline & 1990 & 2004 \\
\hline Afghanistan & 18.2 & - \\
Bangladesh & 19.8 & 24.6 \\
Cambodia & 12.6 & 19.2 \\
China & 27.4 & 39.6 \\
India & 25.5 & 28.5 \\
Indonesia & 30.6 & 46.7 \\
Myanmar & 24.8 & 30.0 \\
Nepal & 9.0 & 15.4 \\
Pakistan & 30.6 & 34.5 \\
Sri Lanka & 21.3 & 21.0 \\
Vietnam & 20.2 & 26.2 \\
East Asia Pacific & 28.8 & 40.6 \\
South Asia & 25.0 & 28.3 \\
\hline Source World Development Indicators 2005, World Bank. & &
\end{tabular}

generally at significantly lower levels. However, accelerating growth will be associated with an increase in the rate of urbanisation, so that South Asia can be seen to be at an earlier stage of the urbanisation process than China. Continued and accelerated urbanisation will be a key feature of the policy environment, while the bulk of the population (and probably the overwhelming proportion of the poorest) will continue to be located in rural areas for at least the next generation.

Even more so in South Asia, both poverty and growth considerations require a high level of attention to rural infrastructure investment.

Table 7 provides information on the allocation of private investment commitments for infrastructure across developing regions during the period 1990-2002. East Asia has been dominated by China which has been much the most successful country in the region in attracting private investment for infrastructure and the flow of investment to China has not been affected by the 1997 crisis and its aftermath which affected other countries (notably Indonesia and the Philippines whose flow of investment has never fully recovered) very severely. South Asia has attracted less than one-quarter of the investment commitments to East Asia, despite having a comparable level of population, although private investment has increased significantly in India. Telecommunications and electricity have been the overwhelmingly most important sectors for private investment in South Asia. In East Asia (mainly China) there have also been substantial investments in toll roads and to a lesser extent in rail and water and sanitation.

CEA identifies the following reasons why the private sector has not lived up to expectations in playing a greater role in the financing and delivery of infrastructure investment and services:

- Unrealistic expectations about the scope for moving from a public to a private role in many sectors

- Local factors were more important than global ones in determining investor response (since private investment in infrastructure in some other areas of the world has recovered more rapidly than in East Asia)

- Lack of infrastructure sector reform and minimal privatisation of existing assets, with little role for competition or independent regulation

- Unpredictable government actions and difficulties in enforcing property rights 
Table 7 Cumulative private investment commitments from 1990-2002

\begin{tabular}{|c|c|c|c|c|c|c|c|c|c|}
\hline Region & Telecom & Electricity & $\begin{array}{l}\text { Natural } \\
\text { gas }\end{array}$ & Airports & Railways & Seaports & $\begin{array}{l}\text { Toll } \\
\text { roads }\end{array}$ & w\&s & Total \\
\hline $\begin{array}{l}\text { East Asia and } \\
\text { Pacific }\end{array}$ & 56.2 & 68.3 & 6.8 & 2.8 & 10.3 & 11.2 & 26.8 & 17.0 & 199.4 \\
\hline $\begin{array}{l}\text { Europe and } \\
\text { Central Asia }\end{array}$ & 68.1 & 21.1 & 11.3 & 1.5 & 0.3 & 1.8 & 2.6 & 3.5 & 110.2 \\
\hline $\begin{array}{l}\text { Latin America } \\
\text { and the } \\
\text { Caribbean }\end{array}$ & 182.9 & 100.4 & 19.5 & 7.5 & 18.3 & 6.9 & 40.6 & 21.3 & 397.4 \\
\hline $\begin{array}{l}\text { M. East and } \\
\text { North Africa }\end{array}$ & 10.6 & 8.4 & 3.9 & 0.9 & 0.2 & 1.2 & - & 1.3 & 26.5 \\
\hline South Asia & 19.7 & 22.6 & 0.2 & 0.2 & - & 2.1 & 0.8 & 0.2 & 45.8 \\
\hline $\begin{array}{l}\text { Sub-Saharan } \\
\text { Africa }\end{array}$ & 18.5 & 5.0 & 1.3 & 0.4 & 0.3 & 0.4 & 2.0 & 0.2 & 28.1 \\
\hline Total & 355.9 & 225.7 & 43.0 & 13.2 & 30.3 & 22.6 & 72.8 & 43.6 & 807.4 \\
\hline
\end{tabular}

Figures in 2002 US\$ billions. W\&S: water and sanitation.

Briceno-Garmendia et al. (2004)

- Lack of clarity in the subsidy framework and political backlashes against tariff increases associated with privatisation

- Continuing state guarantees involving substantial contingent liabilities for governments that in many cases proved impossible to meet after the 1997 crisis

- Flaws in the contractual agreements with the private sector particularly in relation to dealing with severe currency movements

- Tainting of private sector deals with corruption (though it is not clear that this was any worse than it had been in the public sector)

- The need for some experimentation and experience in how best to allocate risk between the public and private sectors.

The scope for private investment in sectors where an appropriate policy and institutional environment can be developed, and where pricing allows cost recovery remains substantial as has occurred in the telecommunications sector in most countries where private investment has been permitted.

2.4 Evidence on the growth and poverty impact of infrastructure in the region

There have recently been attempts to measure empirically the impact of different forms of infrastructure and human capital spending on growth and poverty reduction, though the findings of these studies need to be treated with some caution for drawing current policy conclusions for several reasons, including the age of the data on which they are based (Fan 2003; Fan and Zhang 2004). For China, however, these studies suggest that rural roads emerge empirically as the form of infrastructure spending that has the greatest impact, though returns to education and agricultural research and development emerge as the most effective way to use public expenditure to reduce rural poverty. ${ }^{3}$ In India, by contrast, expenditure on rural roads emerges as the most effective. Fan and Zhang (2004) note two main conclusions from the estimation of production functions for different regions of China ${ }^{4}$ :

'First, rural infrastructure and education play a more important role in explaining the difference in rural non-farm productivity than agricultural productivity. Because the rural non-farm economy is a major determinant of rural income, investing more in rural infrastructure is key to an increase in overall income of the rural population. Second, the lower productivity in the western region is explained by its lower level of rural infrastructure, education, and science and technology. Therefore, improving both 


\section{Box 1 Infrastructure issues for East Asia}

East Asia's strong growth and rising incomes are outpacing infrastructure development. High growth is placing increasing pressure on existing infrastructure across the region. The key regional challenge is to facilitate the progressive improvement of the investment climate for infrastructure as a precondition to attract domestic savings and international capital. Examples abound: Indonesia alone will need 2,000-2,500 MU of new installed capacity annually to sustain a 6 per cent growth rate; the highgrowth coastal provinces of China have recently begun to experience power shortages; and increasing urban motorisation has contributed to acute traffic congestion in major cities across the region. Container berth capacity on East Asia and Pacific (EAP) ports rose by only 8 per cent a year between 1980 and 2000 while container fleet capacity on EAP routes increased by 20 per cent a year.

Growth is being accompanied by rapid urbanisation and rising disparities in access to service. In 2003, some 43 per cent of EAP's population of over 1.8 billion lived in urban areas, with the most rapid growth occurring in the 'peri-urban' outskirts of East Asian cities. The urban population is expected to surpass 50 per cent by 2025. Accompanying this is an increase in urban poverty - projected to rise from 25 per cent in 1998 to 40 per cent by 2025. Unequal access to infrastructure reinforces urban-rural and intra-urban inequality. While electricity access has increased significantly in the region (from 56 per cent in 1990 to 88 per cent in 2002), rural access in many countries is still low relative to urban areas. And within the EAP region's cities, the poor have significantly less access to piped water supply; an estimated 38 per cent of households in informal settlements compared with 66 per cent citywide. In addition, congestion, increasing trip length and deficient public transport services severely impact on the mobility of the poor and the overall quality of urban living.

Coordination between decentralised government authorities is a major challenge. Within less than 20 years, previously centralised state structures have been significantly decentralised in EAP. Sub-national government expenditure as a percentage of total public expenditure now ranges from 10 per cent in Thailand to close to 70 per cent in China. This shift requires new relationships between central and decentralised governments as well as across decentralised authorities to coordinate the planning and financing of infrastructure. Without better coordination, over or under-investment is likely to occur. For example, local level lobbying for air facilities across Thailand resulted in gross oversupply with many local airports now essentially in a state of abandonment. On the other hand, in both Indonesia and the Philippines, regional or provincial authorities have been left without sufficient mandate and resources. As a result of this 'missing middle' issue, the secondary road networks in these countries, for example, are showing signs of neglect and externalities across local jurisdictions are often overlooked when designing infrastructure projects that span municipal boundaries.

Source World Bank (2005: 6-7).

the level and efficiency of public capital in the west is a must to narrow its difference in productivity with other regions'. (Fan and Zhang 2004)

The robustness of the finding of a significant impact of rural (and especially all-weather, paved) roads on poverty reduction emerges from a number of other studies within the region:

- Kwon (2000) found for Indonesia that the poverty impact of growth was almost four times higher in provinces with high levels of road provision compared with those with poor levels of provision. A more disaggregated analysis using district-level data (Balisacan and Pernia 2002b) found a significant effect of roads on the incomes of the poor

- Balisacan and Pernia (2002a) found similar results for the Philippines using provincial data, but also found that the impact is increased if coupled with education investment

- Glewwe et al. (2002) found the poor households living in rural communes with paved roads in Vietnam had 67 per cent higher probability of escaping poverty than those in communes without paved roads. 


\section{Box 2 Infrastructure issues for South Asia}

Extending access to infrastructure services to both businesses and households (especially the poor) will be critical to sustaining the region's high growth rates, and ensuring its benefits are shared with the region's large number of poor. Investment climate surveys routinely show infrastructure as a leading impediment to business growth in South Asia - with shortcomings in electricity service identified as the greatest obstacle to business operation, above corruption and taxes. Infrastructure quality in South Asia is low relative to other regions (with the exception of cell phones) and hundreds of millions of people have no access to basic services. Access to power services ranges from 6 per cent in Afghanistan to 64 per cent in Sri Lanka. Only 39 per cent of Bangladesh households have access to all-season roads and recorded rates of urban water supply and sanitation services vary greatly. Within India, access to water is intermittent in all major cities (e.g. no city with a population of more than 1 million has a 24-hour supply), and access levels range from below 60 per cent in states like Mizoram and Kerala to close to 100 per cent in Punjab and Delhi. The limited reach and poor quality of infrastructure services is a major constraint to growth and achievement of the MDGs.

Across South Asia, the utilities responsible for service provision remain almost universally in the public sector and are characterised by inefficiencies and weak governance. This in turn yields poor and conflicting incentives to provide efficient and reliable service, or to expand services to the poor. Even where significant steps have been taken towards the commercialisation of service provision (e.g. in the power sector), service delivery and pricing generally remain highly politicised - reflected keenly in a political unwillingness to sanction cost-covering tariffs for power services - often at high fiscal costs (in Pakistan, power sector losses are equivalent to 1.5 per cent of GDP). Overall, more emphasis is needed on improving performance and focusing on results and outcomes. In such an environment the private sector appetite for sectoral investments remains limited, with the major exception of telecommunications.

Regional infrastructure integration and energy trade is set to be of increasing importance in the region. The South Asia region has enormous potential for mutually beneficial trade in energy and energy resources. The size and dispersion of its hydropower and natural gas resources, the highly differentiated size of its economies and associated energy demand levels and growth suggest significant benefits from greater integration. The region's proximity to countries in Central Asia and the Middle East with huge proven reserves of natural gas also provides excellent opportunities for importing gas at competitive prices to meet growing needs in the power sector. As intra-regional trade and trade with close neighbours expand, there will be an increasing need to develop new and improve existing transport corridors and bolster the efficiency of transport and trade facilitation services. However, in contrast to the other regions, movement on the regional integration agenda in infrastructure in South Asia has been slow, mirroring the historic slow growth and low level of intraregional trade in general.

\section{Source World Bank (2005: 9-10).}

Cook (2003), summarising studies on China, India, Thailand and Indonesia on determinants of rural poverty reduction, concludes that the consistent finding is that investment in roads and education have been the main drivers of rural poverty reduction (with agricultural research and development also important in those studies where it has been examined). The poverty impact of irrigation and power investments has been positive but significantly smaller. Studies on the impact on income of electricity investment in the Philippines (Balisacan and Pernia 2002a) conclude that there is little effect for the poorest, and suggest that some minimum level of income and of access to complementary facilities is required for households to benefit from electricity.

An ADB impact study of transport and energy investment in China, India and Thailand (ADB 2003) found that: 
- Improvements in transport infrastructure led to significant changes in the use of transport, while electricity when it became available was used mainly for lighting, television and other appliances, while its use for income-generating activities required complementary equipment that was generally beyond the reach of the poor. In both sectors, the regulatory framework and the extent of competition or tariff policy impacted on usage

- In all three country case studies, significant income and poverty reduction effects were found as a result of transport investment (especially paved roads), with electrical connection having a markedly lesser effect

- Again, in all three cases there was substantially improved access to education and health facilities leading to improved school attendance (particularly for girls in India), better trained teachers being willing to relocate, and better health status, although there were concerns about increases in road accidents. Electricity provided more time for study and improving hygiene through refrigeration

- Time savings were particularly valued by the poor, while there appeared to be strong complementarities between different types of investment

- Substantial community level changes were reported including new village markets, increased availability of goods, greater capacity to access work, increased social participation (in politics and community bodies), improved security and access to common resources.

Studies of the impact of alternative approaches to the provision of water and sanitation services in the region have stressed the importance of community involvement, local government capacity building, cost recovery and effective targeting of the poor as elements of a sustainable approach, while noting also that models that work in one context cannot easily be replicated elsewhere.

\section{Infrastructure policy issues}

\subsection{Overview of key policy issues}

CEA identifies 12 key policy conclusions (or elements of a policy framework) for addressing the infrastructure challenge faced by East Asia. These are in part generic problems relating to improving the environment for private investment of all kinds, and for making government more effective and accountable. Others relate more specifically to infrastructure priorities.

1 The centre matters - infrastructure demands strong planning and coordination functions, though these should be developed in the context of democratisation, decentralisation, independent negotiation, private participation and the commercialisation of service providers, rather than a return to top-down detailed economic planning.

2 Decentralisation is important but raises a host of coordination challenges, both vertically and horizontally as the role and capacity of lower tiers of government develops.

3 'Fiscal space' for infrastructure is critical since the capacity for reliance on private financing is always going to be limited. Cost recovery and measures to improve the policy and institutional frameworks within which public investment occurs are key to maximising the returns to public infrastructure investment and creating a virtuous circle of investment and growth.

4 Subsidies can be justified in some circumstances but they always involve the risk of becoming open-ended and are likely not to favour the poor. Output-based approaches are one way of fostering an efficient and limited use of subsidies.

5 Competition is the best way to strengthen accountability, where institutional and technological innovation is expanding the potential for competition.

6 Genuine regulatory independence can only be built over time, and in the short-term rule-based approaches that limit the discretion of regulators may be necessary to provide a predictable and stable environment for investment.

7 Civil society has an important role in ensuring accountability and communities can also manage local infrastructure resources.

8 Controlling corruption is vital and requires a long, hard struggle though short-term reforms can help remove opportunities for rent-seeking.

9 The international private sector remains interested in investing (at least where large market opportunities exist) but is currently constrained by lack of confidence in the predictability of the policy environment.

10 The public sector will maintain a strong role in infrastructure investment in many circumstances so that improving public sector performance remains central, although significant obstacles to 
Table 8 Status of electricity reforms, 2004

\begin{tabular}{lllll}
\hline & $\begin{array}{l}\text { Independent } \\
\text { regulatory agency }\end{array}$ & $\begin{array}{l}\text { Private participation } \\
\text { in generation }\end{array}$ & $\begin{array}{l}\text { Private participation } \\
\text { in distribution }\end{array}$ & $\begin{array}{l}\text { Vertical } \\
\text { integration }\end{array}$ \\
\hline Afghanistan & No & No & No & Yes \\
Bangladesh & Yes & Yes & No & No \\
Cambodia & Yes & - & Yes & - \\
China & No & No & No & - \\
India & Yes & Yes & Yes & No \\
Indonesia & No & Yes & No & - \\
Myanmar & No & - & - & - \\
Nepal & No & No & No & Yes \\
Pakistan & Yes & No & No & No \\
Sri Lanka & Yes & Yes & No & Yes \\
Vietnam & No & No & No & - \\
\hline
\end{tabular}

Estache and Goicoechea (2005).

successful public sector reform are likely to be encountered.

11 Improving the capacity of the local financial markets to mobilise resources will be an important part of a sustainable financing strategy.

12 There is an important role for aid donors especially in the poorer and smaller countries and official financing for infrastructure can be expected to increase.

Boxes 1 and 2 summarise the World Bank's assessment of the differences in the key policy challenges between East Asia and South Asia.

The key difference between the two regions is that South Asian countries (in common with the poorer East Asian economies) face a far more fundamental need substantially to increase investment, probably requiring an approximate doubling of infrastructure investment compared to recent levels, at a time when most countries in the region face considerable fiscal stress and have had limited success in attracting foreign investment for infrastructure or in raising overall investment levels.

CEA has a relatively limited discussion of specific environmental and social issues related to infrastructure, while noting in particular estimates of the substantial costs in health and environmental degradation terms associated with aspects of China's infrastructure policies, notably the heavy reliance on high-sulphur coal for electricity production and the severe degradation of land and water resources, and the increasing attention and concern since 1994 at the policy level in China about environmental issues. CEA treats more effective mainstreaming of environmental concerns as one aspect of the more general challenge of improving governance and accountability that is necessary to improve infrastructure provision and management in all their dimensions, while noting the particularly challenging problems of coordination across sectors and between levels of government that effective attention to environmental issues requires. The environmental implications of mega-dam projects (especially in China but affecting all of the region's major rivers) are issues of particular salience and concern.

\subsection{Progress in infrastructure policy reforms} Tables 8 and 9 provide a summary of the main features of institutional and policy reform in the electricity, water, and ICT sectors. However, the linkages between the progress of institutional reforms and the capacity to mobilise private investment effectively is more complex. Both China and Vietnam have achieved success in attracting private investment in a number of sectors despite limited formal reforms. 
Table 9 Status of water and ICT reforms, 2004

\begin{tabular}{lllll}
\hline & $\begin{array}{l}\text { Independent } \\
\text { regulatory agency }\end{array}$ & Private capital & $\begin{array}{l}\text { Independent } \\
\text { regulatory agency }\end{array}$ & Private capital \\
\hline Ufghanistan & No & ICT & No \\
Bangladesh & No & No & Yes & No \\
Cambodia & No & No & Yes & No \\
China & Yes & No & No & Yes \\
India & No & Yes & No & Yes \\
Indonesia & No & Yes & Yes & Yes \\
Myanmar & - & Yes & Yes & No \\
Nepal & No & - & No & No \\
Pakistan & No & No & Yes & Yes \\
Sri Lanka & No & No & Yes & Yes \\
Vietnam & No & No & Yes & No \\
\hline
\end{tabular}

Estache and Goicoechea (2005).

A further example of the difficulty of bringing about reforms to allow infrastructure to be used more effectively is illustrated by ports in Bangladesh, as discussed in OPM (2002). With outmoded management, information and control systems, the Chittagong port is one of the most inefficient in the region. Its problems are well known and possible changes that have been identified include introducing competition through instating private container facilities (in the form both of a terminal at Chittagong and of Internal Container Depots (ICDs) at number of locations in the country), and restructuring the port and terminal services. With 90 per cent of Bangladesh's external trade moving through the port, the cost to the national economy of this inefficiency has been variously estimated at between US $\$ 0.5$ and US\$1.0 billion per annum. Centralised management and budget arrangements are excessively linked to governmental and political processes, and give insufficient autonomy and incentives for improved performance to local management. Industrial action by the port trade unions has been driven by local and national political issues of a partisan and factional nature. Port users are allegedly obliged to make extra payments to get the work done on time. Reform has not been effectively pursued because of a combination of such perverse incentives and a few vested interests linked to the political process, the bureaucracy, and the unions.

Box 3 illustrates why India has achieved only limited success in attracting private investment in electricity generation despite far-reaching institutional and policy reforms, principally because of the failure to address key constraints arising from pricing and subsidy policies.

\subsection{Regional cooperation in infrastructure}

Jones (2004b) has noted that there have been some important successes in infrastructure cooperation in East Asia, though progress has generally been more limited in South Asia. In particular, planning and institutional frameworks have been established to guide regional cooperation in the development of regional and subregional networks, for instance in relation to roads, rail, gas pipelines and telecommunications systems. The existence of these agreed frameworks facilitates the process of network development and expansion as demand grows and investment resources become available. In other sectors, such as electricity, the development of wider regional cooperation is some way further into the future pending the development and integration of 


\section{Box 3 Obstacles to private power investments in India}

Since 1991, the power sector in India has undergone 'comprehensive and significant reforms'. Stateowned power utilities have been unbundled and corporatised. The reorganisation of distribution activities has begun and the entire distribution system has been privatised in two states. The 1998 legislation recognised transmission as a distinct entity from generation and distribution, and a Central Transmission Utility was established as a building block in the development of competitive power markets, and to establish independent regulatory agencies.

These legislative reforms were consolidated in an omnibus Act in 2003 which harmonised pre-existing laws, strengthened anti-theft provisions, and recognised power trading as a distinct activity and provides private power suppliers with 'open access' to transmission and distribution networks, and de-licensed generation activities (excluding nuclear and hydro). A package of investment incentives was also introduced.

However, less than one-quarter of the hoped-for new private generating capacity came on stream over 1992-2002, and while private sector investment accounts for 10 per cent of installed capacity, this is far lower than had been expected.

While the complexity of the reform implementation process may have slowed reforms and insufficient progress was made in simplifying investment processes, the fundamental obstacle remains the lack of financial viability in the context where State Electricity Boards (SEBs) remain essentially the only buyers of power. SEBs lack financial viability and hence the ability to guarantee payment primarily because of the subsidy policies they follow. For instance, 29 per cent of the power is supplied to the agricultural sector at a tariff that represents only 12 per cent cost recovery, and the average cost recovery is 69 per cent. In 2002, SEBs collectively had losses (even after subsidies from state governments) of Rs248 billion.

The 2003 Act requires moves towards the elimination of cross-subsidies by 2008, but to date little progress has been made in the implementation by most state governments because of the extreme political difficulty of raising power tariffs particularly to the most heavily subsidised agricultural and commercial users.

Source Desai (2004).

national networks and currently initiatives are limited to relatively simple bilateral cross-border arrangements.

The Greater Mekong Subregion (GMS) is an example of a particularly successful regional initiative. Over the 12-year course of its existence, it has steadily evolved from a disparate collection of wary neighbours into a highly effective collaboration that can now point to numerous infrastructure investments directly attributable to the GMS initiative. Moreover, it has accomplished this with a largely informal approach; GMS operates on a selfselection formula of ' $6-x$ ', meaning only those who choose to involve themselves in any particular undertaking are bound by that agreement. Those who 'opt out' are not pressured to participate, nor do they constrain those who wish to proceed within their own territories. Success factors for the GMS include:

- Geography: GMS consists of a reasonably compact land mass wherein every member state shares borders with at least three others thereby making cross-border infrastructure and the benefits immediately recognisable

- Economics: GMS is anchored north and south by the dynamic economies of China and Thailand, increasingly eager for access to one another and to the intervening markets of relatively poorer members who are themselves poised to benefit from subregional trade and infrastructure initiatives

- Sponsorship: While there have been numerous bilateral and multilateral sources of support, ADB 
has committed to a long-term central activist role, serving as a patient broker and neutral coordinator plus a source of technical assistance and, frequently, of project finance

- Budget: To assist in such subregional support, an ADB budget separate from individual national allocations was available.

Shared river resources pose issues for management and potential for conflict that may be particularly related to infrastructure investment and policy decisions, for instance because of the downstream impact of dams or off-take decisions on major rivers such as the Ganges, Brahmaputra, Mekong or Indus that cross national borders. These conflicts are frequently cross-border, though conflicts within countries can be significant (for instance the 2002 conflict between Tamil Nadu and Karnataka over water-sharing from the Cauvery River). While infrastructure decisions in relation to shared water resources may be a source of conflict, it is also notable that some arrangements on the management of common resources (such as the Mekong River Commission and for the Indus River between Pakistan and India) have proved robust even in the face of severe political tensions between the countries involved.

\section{Choices for public action}

While the depth and nature of the infrastructure problem varies across the regions in discussion and to a considerable degree within countries too, the salient issues can be summarised as follows:

- The need to sustain or in most cases significantly increase the proportion of GDP allocated to infrastructure investment. This has a number of dimensions including the reorientation of current spending towards investment, improving the efficiency of procurement and management of public funds, and the possible reassessment of public spending priorities

- The environment for private investment needs to be improved through providing more secure policy environments, protection to property rights, and pricing and subsidy policies that enable economic returns to be made. Private investment can play an important role and has flowed in where opportunities have emerged (at least to the larger countries), but it does not provide a panacea, and even in areas where it is most likely to be attracted, governments may be required to provide guarantees and other forms of support to ensure confidence and viability - these may have a fiscal cost and the failure to manage the allocation of risks appropriately has been a major cause of problems for sustained private investment

- Improving the performance and accountability of the public sector in managing investments and providing services. While cost recovery (directly or through sustainable subsidy systems) is essential for effective public sector operation, there are major challenges in ensuring cost control and containing corruption in the management of monopoly service providers

- There are strong a priori reasons and empirical evidence to suggest that across much of the region rural roads and improved water and sanitation services are the forms of infrastructure investment that will have the greatest positive direct impact on the poor. These are sectors where performance appears to have lagged behind other more dynamic sectors, and where cost recovery and attracting private investment have proved particularly problematic, although there are positive examples

- There has to date been relatively limited progress within the region in effective policy and institutional reform in the sectors where infrastructure is important, particularly outside the telecommunications sector where the rapid pace of technological change has driven reform. The regulatory and wider institutional framework for private sector participation remains generally weak and there is evidence that the governance environment (affecting the quality of public investment as well as the incentives for private investment) across the region is tending to deteriorate rather than to improve

- Pricing policies for infrastructure services often involve subsidies but these appear to be poorly targeted on the poor particularly to the extent that the size of subsidy received is generally proportional to the use of the service, rather than being focused on widening access to those who are currently not served. The political acceptability of cost recovery-based pricing (with water and power being particularly politically controversial in many countries) is especially important in determining the policy options that are available given the competing priorities for public funding

- The extent to which the interests or voices of the poor are reflected in decision making about infrastructure 
(whether at national or local level) is important for determining impact. Community participation plays an important role in ensuring effective and sustainable provision of infrastructure services at the local level, but reaching the poor still poses major challenges.

A critical issue that governments face relates to the decisions on public infrastructure investment priorities (given the implied need for substantial increases in expenditure) and in particular to whether there may be trade-offs between objectives. An important point is that the infrastructure financing needs for water

\section{Notes}

* This report was prepared with research support from Katarina Kotoglou. Thanks are due to reviewers from the World Bank and DFID and to Professor John Humphrey for comments.

1 An important point to note in relation to the first two empirical conclusions is that these results refer to actual infrastructure investment although issues like the siting of investments are known to be susceptible to the influence of political and non-economic factors. These results suggest that the returns for optimal investments could be even higher.

2 CEA Figure 2.4 (ADB/JBIC/WB (2005) [CEA]) presents estimates that infrastructure investment in Vietnam has remained between 8 and 10 per cent of GDP throughout the period from 1995-2003.

\section{References}

ADB (2003) Assessing the Impact of Transport and Energy Infrastructure on Poverty Reduction-Country Case Study of the Peoples Republic of China, Final Report, Asian Development Bank

ADB/JBIC/WB (2005) [CEA] Connecting East Asia: A New Framework for Infrastructure, joint study, Asian Development Bank/Japan Bank for International Cooperation/World Bank

Balisacan, A.M. and Pernia, E.M. (2002a) Probing Beneath Cross-national Average: Poverty, Inequality and Growth in the Philippines, ERD Working Paper Series 7, Manila: Economics and Research Department, Asian Development Bank

Balisacan, A.M. and Pernia, E.M. (2002b) Revisiting Growth and Poverty Reduction in Indonesia: What do Subnational Data Show?, ERD Working Paper Series 25, Manila: Economics and Research Department, Asian Development Bank

Briceno-Garmendia, C., Estache, A. and Shafik, N. (2004) Infrastructure Services in Developing and sanitation (which has direct and well-established benefits for health and well-being) are relatively modest in comparison to the likely demand in ICT and power, which the private sector should be attracted to provided the appropriate policy framework is in place. China's success suggests that private financing can have a significant role in the development of major road networks which may also allow some public resources to be freed for the development of rural and feeder roads that have been established to have a strong poverty impact and which will remain of key importance in South Asia where endemic rural poverty is still the main problem.

3 Fan et al. (2002) found that increases in road density had significant effects on agricultural GDP per worker, non-agricultural employment and agricultural wages. Jalan and Ravallion (2002) also found for China that a 1 per cent increase in road $\mathrm{km}$ per capita led to an increase in household consumption of 0.08 per cent.

4 Luo (2004) shows that geographical position was a significant factor in explaining differences in growth rates between provinces in China from 1979-99. Her analysis suggests though that improvement in transportation infrastructure in central hubs (Hubei, Henan and Hunan) will have a greater effect on development in Western China than the same level of investment within Western China itself.

Countries: Access, Quality, Costs and Policy Reform, Policy Research Working Paper 3468, Washington DC: World Bank, December Cook, C.C. (2003) 'The Role of Infrastructure and Infrastructure Services in Poverty Reduction', background paper for the ADB Poverty Reduction Strategy Review

Desai, V.V. (2004) Obstacles to Private Power Investments in India, Discussion Paper 20, ADB Institute, December

Estache, A. (2004) 'Emerging Infrastructure Policy Issues in Developing Countries: A Survey of the Recent Economic Literature', background paper for October 2004 meeting of the POVNET Infrastructure Working Group

Estache, A. and Goicoechea, A. (2005) A 'Research' Database on Infrastructure Economic Performance, Policy Research Working Paper 3642, Washington DC: World Bank, June

Fan, S. (2003) 'Public Investment and Poverty Reduction: What Have We Learnt from India and 
China', IFPRI (International Food Policy Research Institute) paper prepared for the ADBI conference 'Infrastructure Investment for Poverty Reduction: what do we know?' Tokyo, 12-13June

Fan, S. and Zhang, X. (2004) 'Infrastructure and Regional Economic Development in Rural China', China Economic Review 15: 203-14

Fan, S., Zhang, L. and Zhang, X. (2002) Growth, Inequality, and Poverty in Rural China: The Role of Public Investments, Washington DC: International Food Policy Research Institute

Fay, M., and Yepes, T. (2003) Investing in Infrastructure: What is Needed from 2000 to 2010?, Policy Research Working Paper 3102, Washington DC: World Bank, July

Glewwe, P., Gragnolati, M. and Zaman, H. (2002) 'Who Gained from Vietnam's Boom in the 1990s?', Economic Development and Cultural Change 50.4: 773-92

lanchovichina, E. and Kacker, P. (2005) Growth Trends in the Developing World: Country Forecasts and Determinants, Policy Research Working Paper 3775, Washington DC: World Bank, November Jalan, J. and Ravallion, M. (2002) 'Geographic Poverty Traps? A Micro Model of Consumption
Growth in Rural China', Journal of Applied Econometrics 17.4: 329-46

Jones, S. (2004a) 'Contribution of Infrastructure to Growth and Poverty Reduction in East Asia and the Pacific', background paper, Oxford Policy Management, October

Jones, S. (2004b) 'Regional Integration through Cross-border Infrastructure - Framework Paper', Oxford Policy Management, November Kwon, E. (2000) A Link Between Infrastructure, Growth, and Poverty in Indonesia: Stage 1 Report, Economics and Development Resource Center, Asian Development Bank

Luo, X. (2004) The Role of Infrastructure Investment Location in China's Western Development, Policy Research Working Paper 3345, Washington DC: World Bank

OPM (2002) Bangladesh: Supporting the Drivers of ProPoor Change, Report for Department for International Development (DFID), Oxford Policy Management

World Bank (2005) Infrastructure and the World Bank: A Progress Report, Infrastructure Vice Presidency, 6 September 